\title{
PENINGKATAN KEMAMPUAN BELAJAR MATEMATIKA SISWA KELAS X TATA BUSANA (TB -1) MATERI PERBANDINGAN TRIGONOMETRI PADA SEGITIGA SIKU-SIKU MELALUI METODE DISCOVERY LEARNING PADA SMK NEGERI 1 SIGLI
}

\author{
Almaida \\ SMK Negeri 1 Sigli \\ Email : almaida308@gmail.com
}

\begin{abstract}
ABSTRAK
Rendahnya penguasaan kemampuan siswa pada pelajaran Matematika kemungkinan besar dikarenakan guru kurang tepat dalam memilih metode dalam pembelajaran. Penelitian ini dilakukan di SMK Negeri 1 Sigli selama tiga bulan sejak bulan Februari sampai Mei 2018 bertujuan untuk meningkatkan kemampuan belajar matematika siswa kelas X Tata Busana materi perbandingan trigonometri pada segitiga siku-siku melalui metode discovery learning pada SMK Negeri 1 Sigli. Metode penelitian yang digunakan adalah penelitian tindakan kelas (PTK) Yang terdiri atas 2 siklus. Subyek penelitian adalah siswa-siswi Kelas X TB - 1 SMK Negeri I Sigli sebanyak 30 siswa. Analisis data menggunakan teknik analisis deskriptif komparatif dengan membandingkan kondisi awal dengan hasil-hasil yang dicapai pada setiap siklus dan analisis deskriptif kualitatif hasil observasi dengan membandingkan hasil observasi dan reflekksi pada siklus I dan siklus 2. Dalam penelitian ini menggunakan metode discovery learning dengan materi perbandingan trigonometri pada segitiga siku-siku, diperoleh hasil tes pada siklus I dengan persentase ketuntasan sebesar 56,70\%, nilai rata-rata kelas sebesar $66.1 \%$ dan meningkat pada hasil tes siklus II sebesar $90 \%$ dengan nilai rata-rata kelas $74.6 \%$. Pada kedua siklus ini terjadi perubahan áktifitas dan perolehan nilai yang signifikan bila dibandingkan dengan pra siklus dengan ketuntasan belajar yang hanya mencapai $36.7 \%$ dan nilai rata-rata adalah $58.5 \%$. Dengan demikian melalui penggunaan metode discovery learning dapat meningkatkan kemampuan belajar matematika siswa kelas X TB - 1 dalam materi perbandingan trigonometri pada segitiga siku-siku pada SMK Negeri 1 Sigli.
\end{abstract}

Kata Kunci: Kemampuan Belajar, Metode discovery learning, Perbandingan Trigonometri pada segitiga siku-siku

\section{PENDAHULUAN}

Secara umum matematika merupakan pelajaran yang dianggap sulit dan tidak disukai oleh siswa, umumnya siswa tidak menyukai pelajaran matematika dan merasa sulit untuk mengikutinya. Oleh karena itu, hasil pembelajaran matematika tidak sesuai dengan yang diharapkan.

Berdasarkan hasil ulangan harian siswa kelas X Tata Busana ( $\mathrm{Tb}-1)$ SMK Negeri 1 Sigli dari jumlah siswa sebanyak 30 orang, hanya 11 orang siswa atau $36,7 \%$ yang memperoleh ketuntasan belajar. Sedangkan 19 orang atau $63,3 \%$ siswa memperoleh nilai di bawah KKM (Kriteria Ketuntasan Minimal).

Rendahnya penguasaan kemampuan siswa kemungkinan besar dikarenakan guru kurang tepat dalam memilih metode dalam pembelajaran. Oleh karena itu penulis berusaha untuk mencari solusi, salah satunya adalah dengan menggunakan metode 
discovery learning. Dengan menggunakan metode tersebut diharapkan siswa dapat lebih aktif, kreatif sehingga lebih banyak siswa yang mencapai ketuntasan dalam pembelajaran.

Berdasarkan latar belakang di atas maka penulis melakukan suatu penelitian berjudul "Peningkatan Kemampuan Belajar Matematika Siswa Kelas X Tata Busana (Tb - 1) Materi Perbandingan Trigonometri pada Segitiga Siku-Siku melalui Metode Discovery Learning pada SMK Negeri 1 Sigli”.

\section{KAJIAN KEPUSTAKAAN}

Belajar adalah proses perubahan pengetahuan, maupun perubahan tingkah laku. Apabila setelah belajar tidak terjadi perubahan dalam diri manusia, maka tidak dapat dikatakan bahwa padanya tidak berlangsung proses belajar itu. Sehubungan dengan hal ini. Slameto (2003) mengatakan: "belajar adalah suatu proses yang dilakukan individu untuk memperoleh perubahan tingkah laku yang baru secara secara keseluruhan". Perubahan tingkah laku itu akan dapat melalui berbagai hasil pengalaman individu itu sendiri dalam interaksi dengan lingkungannya.

Perubahan tingkah laku yang dapat diamati dari penampilan orang yang belajar adalah hasil belajar. Pada hakikatnya hasil belajar menunjukkan tingkat kemampuan siswa dalam mengikuti suatu proses pembelajaran. Tingkat kemampuan siswa dari hasil belajar ini dapat dilihat dari kemampuan kognitif, afektif dan psikomotorik (Sutrisno, 2006).

Reigeluth (dalam Sutrisno, 2006) Menurut Slavin (2009), dalam pembelajaran dengan penemuan siswa didorong untuk belajar sebagai besar melalui keterlibatan aktif mereka sendiri dengan konsep-konsep dan prinsip-prinsip, dan guru mendorong siswa untuk memiliki pengalaman dan melakukan percobaan yang memungkinkan mereka menemukan prinsip-prinsip untuk diri mereka sendiri. Reigeluth (dalam
Sutrisno, 2006) menyatakan bahwa hasil belajar dipengaruhi oleh interaksi antara metode pengajaran dan kondisi pengajaran. Hal-hal yang termasuk metode pengajaran antara lain strategi pengorganisasian, strategi pengelolaan pembelajaran dan penyampaian.

Discovery learning menurut Jerome Bruner adalah metode belajar yang mendorong siswa untuk mengajukan pernyataan dan menarik kesimpulan dari prinsip-prinsip umum praktis contoh pengalaman. Dan menjadi dasar ide J. Bruner ialah pendapat dari piaget yang menyatakan bahwa anak harus berperan secara aktif didalam belajar di kelas. Untuk itu Bruner memakai cara dengan apa yang disebutkan discovery learning, yaitu dimana murid mengorganisasikan bahan yang dipelajari dengan suatu bentuk akhir.

\section{Strategi-strategi dalam Pembelajaran Discovery Learning}

Dalam pembelajaran dengan penemuan dapat digunakan beberapa strategi, strategistrategi yang dimaksud adalah sebagai berikut:

a. Strategi Induktif

Strategi ini terdiri dari dua bagian, yakni bagian data atau contoh khusus dan bagian generalisasi (kesimpulan). Data atau contoh tidak dapat digunakan sebagai bukti, hanya merupakan jalan menuju kesimpulan. Mengambil kesimpulan (penemuan) dengan menggunakan strategi induktif ini selalu mengandung resiko, apakah kesimpulan itu benar ataukah tidak. Karenanya kesimpulan yang ditemukan dengan strategi induktif sebaiknya selalu menggunakan perkataan "barangkali" atau "mungkin".

b. Strategi deduktif

Dalam matematika metode deduktif memegang peranan penting dalam hal pembuktian. Karena matematika berisi argumentasi deduktif yang saling berkaitan, makna metode deduktif memegang peranan penting dalam pengajaran matematika. Dari konsep matematika yang bersifat umum yang sudah diketahui siswa sebelumnya, siswa 
dapat diarahkan untuk menemukan konsepkonsep lain yang belum ia ketahui sebelumnya. Sebagai contoh, untuk menentukan rumus luas lingkaran, siswa dapat diarahkan untuk membagi kertas berbentuk lingkaran menjadi $\mathrm{n}$ buah sector yang sma besar, kemudian menyusunnya sedemikian rupa sehingga berbentuk seperti persegi panjang dan rumus keliling lingkaran yang sudah diketahui sebelumnya, siswa akan dapat menemukan luas lingkaran.

\section{METODE PENELITIAN}

Penelitian dilaksanakan di SMK Negeri 1 sigli di kelas $\mathrm{X}$ Tata Busana (Tb-1) pada materi perbandingan trigonometri pada segitiga siku-siku.

Penelitian ini dilaksanakan selama 3 bulan yaitu pada bulan Februari s/d Mei 2018 semester genap tahun pelajran 2017/2018. Subjek penelitian adalah siswa-siswi kelas $\mathrm{X}$ $\mathrm{Tb}$ - 1 dengan jumlah siswa sebanyak 30 orang yang terdiri dari 30 orang siswa perempuan. Data yang diperoleh berasal dari siswa kelas X Tb - 1 dan guru/teman sejawat yang merupakan guru kolaborasi di SMK Negeri 1 Sigli.

Metode yang digunakan adalah Penelitian Tindakan Kelas (PTK) yang terdiri dari 2 siklus. Pada siklus pertama terdiri dari 2 kali tatap muka dan siklus kedua terdiri dari 2 kali tetap muka. Alokasi waktu untuk setiap tatap muka adalah 2 jam pelajaran.

Teknik pengumpulan data yang dilakukan adalah observasi dan tes. Alat pengumpulan data yang digunakan adalah: Lembar instrument aktifitas siswa dalam PBM, Lembar intrumen PBM guru dan butir soal test. Analisis data yang digunakan adalah analisis deskriptif komparatif dan deskriptif kualitatif.

Dalam penelitian PTK menggunakan dan mengembangkan siklus yang mengandung empat komponen yaitu: rencana tindakan (planning), (2) pelaksanaan (action), (3) observasi (observation), (4) refleksi (reflection).

\section{HASIL PEMBAHASAN}

Berdasarkan hasil pengamatan pada siklus I dan siklus II mengalami peningkatan hasil belajar dan juga aktivitas baik bagi guru maupun bagi siswa dalarn kegiatan belajar mengajar dan rnencapai ketuntasan. Hasil tes pada siklus I dengan persentase ketuntasan sebesar $56.7 \%$ nilai rata-rata kelas sebesar 66.1 dan hasil tes siklus II sebesar 90\% dengan nilai rata-rata kelas 74.6. Maka terlihat bahwa nilai siswa telah mencapai standar ketuntasan secara klasikal pada siklus 11 yaitu $85 \%$. Mulyana (2005:99) menyatakan. "keberhasilan kelas dilihat dan jurnlah peserta didik yang mampu menyelesaikan atau mencapai sekurangkurangnya $85 \%$ dan jumlah peserta didik yang ada di kelas tersebut. Dengan demikian dapat disimpulkan terdapat peningkatan hasil belajar siswa selama dua siklus dan telah tuntas secara kiasikal pada mateni perbandingan trigonometri pada segitiga siku-siku dengan menggunakan metode discovery learning. Hal ini disebabkan adanya peningkatan interaksi yang terjadi sehingga mengakibatkan efek yang positif terhadap pemaharnan siswa dalam mempelajari materi ajar. Hasil tes pada siklus I dan II berbeda dengan hasil tes pra siklus dengan perolehan nilai rata-rata kelas adalah 58.5 dan ketuntasan siswa yang dicapai hanya $11 \%$.

Tabel Hasil Belajar Siswa Gabungan

\begin{tabular}{|c|c|c|c|c|c|c|c|}
\hline \multirow{2}{*}{ No } & \multirow{2}{*}{$\begin{array}{c}\text { Ketuntas } \\
\text { an }\end{array}$} & \multicolumn{2}{|c|}{ Pra Siklus } & \multicolumn{2}{c|}{ Siklus I } & \multicolumn{2}{c|}{ Siklus II } \\
\cline { 3 - 8 } & Tuntas & 11 & 36.7 & 17 & 56.7 & 27 & 90 \\
\hline 2. & $\begin{array}{l}\text { Tdk } \\
\text { tuntas }\end{array}$ & 19 & 63.3 & 13 & 43.3 & 3 & 10 \\
\hline \multicolumn{2}{|c|}{ Jlh siswa } & \multicolumn{2}{|c|}{30} & \multicolumn{2}{|c|}{30} & \multicolumn{2}{|c|}{30} \\
\hline \multicolumn{2}{|c|}{ Rata kelas } & \multicolumn{2}{|c|}{58.5} & \multicolumn{2}{|c|}{66.1} & 74.6 \\
\hline
\end{tabular}

Aktivitas siswa pada siklus I masih termasuk kategori cukup dengan persentase sebesar $38.18 \%$ dan aktivitas guru dalam proses pembelajaran siklus I sudah cukup baik dalam hal menyampaikan materi, mengorganisir siswa dan mengelola kelas 
dengan persentase $61.25 \%$. Pada siklus II aktivitas siswa semakin meningkat dengan kategori sangat baik dalam hal bertanya. tampil ke depan kelas, bekerjasarna, mengkondisikan diri dalam kelompok. dan juga memberi tanggapan terhadap hasil presentasi temannya dengan persentase sebesar $81 \%$. Hal ini dikarenakan siswa sudah terbiasa dengan penggunaan metode discovery learning dan juga siswa sudah terbiasa berbaur dalam kelompoknya.

\section{KESIMPULAN}

Berdasarkan hasil penelitian ini dapat disimpulkan bahwa dengan rnenggunakan metode discovey learning dapat rneningkatkan kemampuan belajar matematika siswa kelas X Tata Busana ( $\mathrm{Tb}-$ 1) dalam materi perbandingan trigonometri pada segitiga siku-siku pada SMK Negeri 1 Sigli. Peningkatan kernampuan belajar siswa tersebut terlihat dalarn hal meningkatnya nilai rata-rata. persentase ketuntasan siswa dan juga suasana belajar siswa yang berbeda dan suasana belajar sebelum dilakukan tindakan.

1. Hasil perolehan pada siklus I dengan persentase ketuntasan sebesar $56.7 \%$ nilai rata-rata kelas sebesar 66.1 dan rneningkat pada hasil tes siklus II sebesar 90\% dengan nilai rata-rata kelas 74.6. Pada kedua siklus ini terjadi perubahan aktifitas dan perolehan nilai yang signifikan bila dibandingkan dsengan pra siklus dengan ketuntasan belajar yang hanya mencapai $36.7 \%$ siswa.

2. Adapun hasil pengamatan pada proses belajar mengajar menunjukkan aktivitas siswa lebih meningkat selama proses pembelajaran berlangsung, baik pada siklus I maupun pada siklus II dibandingkan dengan suasana belajar siswa yang pasif dan kaku sebelum dilakukannya tindakan kelas. Perolehan persentase keaktifan siswa pada sikius I adalali $38.18 \%$ dan pada siklus II adalah $61.25 \%$. Aktivitas guru juga meningkat pada siklus I dan siklus II dalam hal penggunaan alat peraga dengan perolehan persentase skor adalah $43.75 \%$ dengan kategori cukup menjadi $81.8 \%$ pada siklus II dengan kategori baik.

Merujuk dari hasil penelitian yang diperoleh, penulis dapat menyarankan antara lain: pertama agar para guru dapat menggunakan metode discovery learning pada materi bahasan lainnya yang berhubungan dengan peristiwa sehari-hari, sehingga konsep-konsep matematika tidak mudah terlupakan. Penggunaan materi pembelajaran yang lebih baik akan berdampak positif dalam hal siswa mengalami perubahan konsep diri dan motivasi berprestasi.

\section{DAFTAR PUSTAKA}

Aqib, Zainal, 2010. Penerbit Tindakan Kelas. Bandung :Yrama Widya.

Budinigsih . Asri . 2005. Belajar dan Pembelajaran. Jakarta: Rinekacipta

Dahar, R.W. 2006. Teori-teori Belajar. Jakarta :Erlangga.

Djamarah. Syaiful Bahri .2002. Prestasi Belajar dan Kompetensi Guru. Surabaya: Usaha Nasional

Ebell. Margaret. 1991. Belajar dan Membelajarkan . Jakarta: Rajawali Pers

Hamalik. Oemar. 2001. Proses Belajar Mengajar. Jakarta: Bumi Aksara.

Hamalik. Oemar. 2008. Kurikulum dan Pembelajaran . Jakarta: Bumi Aksara 
Jurnal Sosial Humaniora Sigli (JSH)

p ISSN : 2615-3688

$e$ ISSN : 2716-0270

http://journal.unigha.ac.id/index.php/JSH

Rahmadi Widdiharto, 2004. Model-Model

Pembelajaran Matematika SMP,

Yogyakarta: Dirjen Dikdasmen

PPPG Matematika
Slameto . 2003. Belajar dan Faktor-faktor yang Mempengaruhinya. Bandung : PT. Reneka Cipta.

Slavin. Robert E. 2009. Cooperative Learning Teori, Riset dan Praktik. Bandung: Nusa Media. 